\title{
Miks haavalehed värisevad? Puudega seotud etioloogiliste tekstide peajooni
}

\author{
Andres Kuperjanov \\ Eesti Kirjandusmuuseumi folkloristika osakonna teadur \\ cps@folklore.ee
}

\begin{abstract}
Teesid: Artikli eesmärk on esitada digitaliseeritud materjali põhjal ülevaade puudega seotud etioloogilistest legendidest, nende lugude peamistest motiividest ning neis esinevatest tegelastest. Esitatakse kõige levinumate tegelastega seotud motiivid, selle järel puuliikide kaupa sagedasemad motiivid ja allmotiivid. Kuna eesti materjal on suhteliselt raskesti kättesaadav ega ole tõlgitud teistesse keeltesse, on püütud esitada võimalikult palju näitetekste. Võimalusel on osutatud jututüüpidele, kasutades Antti Aarne (1918) kataloogi ning Vaina Mälgu, Ingrid Sarve ja Richard Viidalepa (1967) koostatud teaduslikku muinasjutuantoloogiat. Artikkel on väike sissevaade töösolevasse Monumenta sarja kuuluvasse puid käsitlevasse monograafiasse.
\end{abstract}

Märksõnad: etioloogilised legendid, haab, Jeesus, lehed värisevad, puud, rahvapiibel, rist marjal, tekstikorpus

Eesti Kirjandusmuuseumi folkloristika osakond on sisestanud alates 1995. aastast enam kui 150000 käsikirjalist usundilise sisuga teksti, kokku 24 kogust. Neist suurimad on Jakob Hurda kogu (H, 1860-1906), Matthias Johann Eiseni rahvaluulekogu (E, 1880-1934), Eesti Rahvaluule Arhiivi kogu (ERA, 19201944) ning Riikliku Kirjandusmuuseumi kogu (RKM, 1945-1996), igaühest neist on sisestatud üle 30000 temaatilise teksti. Puudega on otseselt seostatud üle 21000 teksti, kusjuures lisaks on puid mainitud veel teistes tekstides ligi 400 erinevas kombinatsioonis. Olulisimad tekstid seotud rahvameditsiini, kalendritavade, rahvaastronoomia, saagiennustuse (karja ja vilja) ning igapäevase majapidamiskasutusega. Ka suur osa peidetud varanduse narratiividest seostub puudega.

Puuliike võib neis tekstides leida üle 30, liigid on eristatavad umbes pooltes puutekstides, mis on üle 10000 teksti, enim on mainitud pihlakas, kask, kuusk ja lepp.

Folkloristika osakonna sisestatud materjalidele tuginedes keskendun siinkohal puudega seotud etioloogilistele legendidele, erinevate puuliikide omaduste tekkele interaktsioonis mütoloogiliste/mütologiseeritud tegelastega, nende lugude põhi-ja alammotiividele. Etioloogilisi legende, mis seletavad subjektide 
päritolu ja omaduste teket, ei ole sügavuti uuritud, mõningase koguse tekste on avaldanud Matthias Johann Eisen 20. sajandi alul, tekste on sisaldanud regionaalväljaanded ja neid on ümber jutustatud lastele.

Meil on küll jutte suurte puude tekkimise kohta, nt puu kasvas Rootsi kuninga kepist, puudeks muutusid pulmalised, jäänukid vanadest (pühadest) puudesaludest. Puude endi loomisest ega päritolust aga jutte ei leidu. Samas on üsna huvitav ja kompaktne rohkem kui saja tekstiga massiiv puude omaduste tekkimise kohta, mis on otseselt seotud mütologiseeritud tegelaste tegevusega. Puudest paistab selles massiivis eriliselt silma haab, tema eritunnuseks on värisevad lehed ja selle põhjenduseks on toodud kümneid lugusid (Aa US 77). Ainult ühes puude omadusi seletavas haaba sisaldavas loos ei mainita haavalehtede värisemist, aga jutustaja on ilmselt selle lihtsalt hetkeks unustanud, või kogemata vahele jätnud.

Etioloogilisi narratiive on kõige rohkem haava, seejärel kuuse ja kadaka kohta, vähem kase ja lepa kohta, veel vähem pihlaka ja tamme kohta ning need puuduvad täiesti toominga kohta. Samas on eriti kase, kuid ka teiste puude kohta märkimisväärselt suuremal arvul muid jutte ja etioloogiliste juttude osakaal on väike või tagasihoidlik. Lugude proportsioone kajastab joonis 1 .

Puude omaduste tekkimise aeg on üsna täpselt määratletud: siis kui puud veel rääkisid, Jeesus (eesti juttudes kasutatakse ainult eesnime versioone, Kristus on haruldane) ja Vanaisa (Jumal) meie metsades ringi käisid, Jeesuse ema Maarja koos Jeesusega Egiptusest põgenes, Jeesus taevasse läks jne.

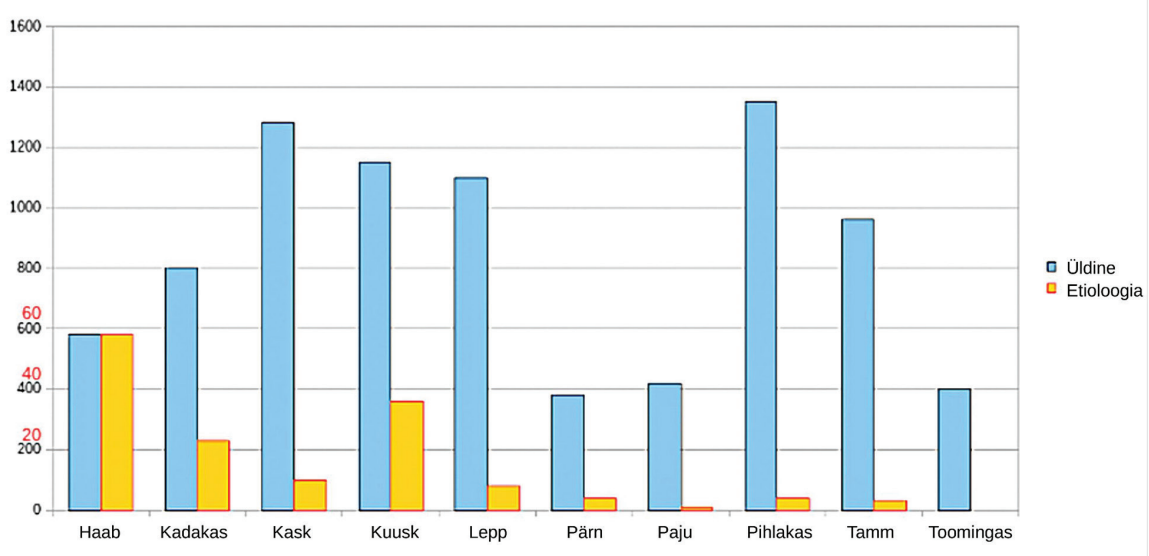

Joonis 1. Puude liigiline jaotus üldtekstides ja etioloogilisi motiive sisaldavates tekstides. 


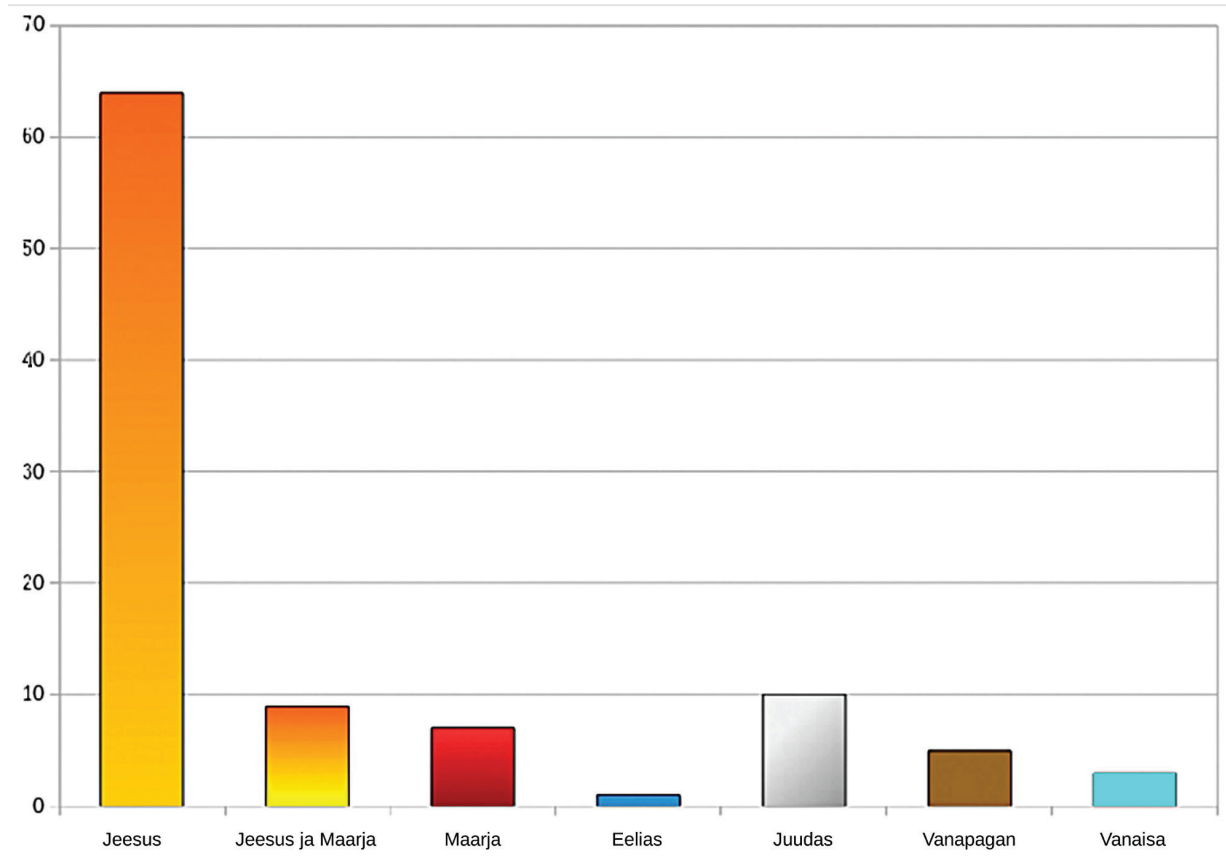

Joonis 2. Mütoloogiliste ja kristlike tegelaste osalus vaadeldavates tekstides.

Tegelaste esinemissagedus lugudes on väga erinev: absoluutne favoriit on Jeesus, kõiki muid tegelasi on vaevalt kuuendik Jeesuse esinemissagedusest (Maarja ja Juudas on ligikaudu võrdse esinemusega, samas vanapagan ja vanaisa (Jumal) on omakorda eelmistest ligi poole väiksema esinemusega ja Elias esineb marginaalselt). Seda toimumisaega nimetatakse müüdiliseks esiajaks, mida iseloomustavad hoopis teised tunnused kui lähemat minevikku või olevikku: seal liiguvadki ringi religioossed tegelased, hiiud, jumal, vanapagan (ka paralleelide kontekstis ebapuhtad jõud). Samas on tegevuskoht paigutatud tuttavasse lokaalsesse ümbrusse, mis loob inimeste maailma ja müüdilise aegruumi kontiinumi.

Piibli esimesed tõlked ilmusid juba 16. sajandil, piibli täistekstide tõlge ilmus 18. sajandi esimesel poolel. Piibel ja võimalikud jäljed luterluse eelsest katoliiklusest ning ortodoksselt alalt ka sealsed pühakulood (nt Maarja männi otsas - RKM II 44, 511 (1) < Setumaa, Obinitsa) on ilmne etioloogiliste tekstide alus. Piiblitekstide luterlik tõlge on olnud ka saksa rahva ühendaja ja mitmed motiivid on saanud rahva hulgas liikunud narratiivide aluseks (Tuczay 2017: 134). 
Maarjaga seotud tekstide ideoloogiliseks aluseks on Maarja põgenemise lugu Pseudo-Matteuse evangeeliumist (Liber de Infantia Mariae et Christi Salvatoris), tuntud marialoogide ühe tüvitekstina, kust (muidugi on varjuandvaks puuks palmipuu, õpetaja Levi lööb Jeesusele stüüraksipuust (Styrax officinalis) kepiga vastu pead, pääsupesa on loorberipuus - PM) meile tuttavaid puid ei leia, samas tegevusliini üksikud komponendid on meie juttudes esindatud. Eesti üks tuntumaid muistendeid räägib põhjustest, miks puudelt võeti kõnevõime (Aa US 75). Järgnevas näitetekstis, mis on ülevaatlik kompilatsioon vaatluse all olevatest etioloogilistest tekstidest, on selle muistendiga kontamineeritud teisi sobivaid puudega seotud muistendeid, nagu kuuse igihaljus vihma eest kaitse pakkumise eest (Aa US 80), Maarja ja Jeesuse ees aupakkumatult käitunud haava lehed jäävad värisema (variant tüübist Aa US 77).

\section{Puud.}

Vanal ajal võisid puud rääkida. Nü̈̈d on neil ka hing sees, mis sellest tunda on, et nad kasvavad, õisi ja vilju kannavad, mis ühel maha raiutud puul võimatu on, aga nende kõne on neilt ära võetud.

Üks talunik läks metsa puid raiuma. Esimene puu, mille ta maha pidi raiuma, oli kuusk, aga tema seest kostis üks hääl temale vastu: “Ära raiu mind mitte! Kas sa ei näe, kui sitked silmapisarad minu ihust välja tungivad? Sa peaksid kahju saama, kui sa minu elu võtaksid.” Talunik läks nü̈̈d männa juure ja tõstis kirve selle vastu ülesse. Puu hing aga hü̈̈dis tema vastu: "Ära raiu mind mitte. Minust oleks sul vähä kasu, sest minu puu on keerd ja oksline.” Paha meelega pööras talunik enese kolmandama puu, lepa poole ja hakkas seda maha raiuma. Puu vaim aga karjus: "Hoia, et sa minusse ei puutu! Iga hoobiga tungib veri minu südamest välja ja värvib minu puu ja sinu kirve verega." Kurb niisuguste keeldude pärast, ei püüdnudki ta enam puid raiuda ja hakkas kodu poole minema. Kui ta metsast välja astus, tuli Jeesus tema vastu ja küsis: mikspärast ta nõnda kurb olla. Ta jutustas temale oma kahju lugu metsas. Siis vastas temale Isand: "Pööra aga tagasi ja raiu maha, mis sa tahad, sest siitsaadik tahan ma puudel ära keelata kõnelemast ja vastu rääkimast." See sündis nõnda, ja sellest saadik ei julge ükski puu inimese kirve vastu häält tõsta. Ometi kuulukse metsas veel vaikist kahinat ja lehtede liikumist, kui puud üksteisega sosistavad.

Ükskord läks Jeesus suure vihma ajal läbi paksu metsa ja otsis puude all vihma eest varju. Kõik puud aga tõmbasid omad oksad tagasi, ehk raputasid endid nii, et veetilgad Jeesuse pääle langesid ja tema hoopis märjaks sai. Ainult kuusk laotas omad arud lahkelt kaitstes välja, mille 
all ta julgelt varjupaika leidis. Tänades läks ta säält varjupaigast ära ja andis kuusele selle õnnistuse, et ta suvel ja talvel haljas pidi olema.

Ka Jeesuse ema Maria käis ükskord oma lapsega läbi metsa, kus kõik puud aupaklikult omad pead teda teretades tema ette nikutasid. Ainult haav seisis külmalt paigal, oma lehti ja oksi ülespidi hoides. Sääl mõistis neitsi Maria selle nuhtluse tema üle, et tema lehed kõige vähäma tuule juures sinna ja tänna liikuma ja värisema pidid.

Hiljemalt saanud Kristuse rist haava puust raiutud, kui teda risti surma oli mõistetud. (H II 42, 358/60 (22) < Halliste khk)

\section{Haab (Populus tremula)}

Haab ise on Eesti metsades suhteliselt tavaline, tarbepuuna kasutati teda paatide, seakünade, sõelakerede jms tegemiseks, samuti ehitusel. Samas kasutati teda ka raviks, haaba kartis halltõbi (malaaria), kõhulahtisuse ja kopsuhaiguste vastu sobis haavapuu koor, maksalutikaga lammastele söödeti haavapuu oksi, haavapuu vahtu kasutati soolatüügaste raviks jne. Peamine keeld oli kasutada sauna kütmiseks haavapuud - nahk võis hakata sügelema, ja ühes tekstis kardeti ka sauna põlemaminekut. Haavapuu lehte on seostatud peidetud varandusega. Haava maagilisteks omadusteks oli tuleviku nägemine kolme haavahalu tules ja nõiduse hävitamine nõiutud eseme põletamisel haavahalgudega. Haavahalgu on kasutatud vahetatud lapse motiivis. Keeleliselt on sõnadel haab ja haav samu sõnavorme, sedagi on ühes tekstis püütud omal moel seletada:

Kui Jeesus Kolgatal risti peal oli, siis kõik puud ja loodus leinasid, aga haava puu seisis uhkeste püsti ladvaga, ja ütles: "Mis mul sest on, kui üks väike inime puu peal ripub!” Ingel kuulis seda ja võttis verd Jeesuse naela haavadest, valas seda haava juurte peale ja ütles: "Sest tunnist saadik pead sa hirmu tundma ja alati värisema!" Ja haavalehed värisevad tänapäevani. (ERA II 148, 264/5 (36) < Märjamaa khk)

Seega on tagasihoidlik puu teeninud oma värisevate lehtedega erilise tähelepanu, kuid puude omaduste tekkimise spekter on õnneks siiski natuke laiem. Järgnevalt tutvustame nende lugude tegelasi.

Puudest kuuluvad sellesse kogumisse haab, kadakas, kuusk, lepp, mänd, kask ja pihlakas, üksiktekstides paju, mainitakse veel saart, remmelgat, tamme, sangleppa ja kuslapuud. 


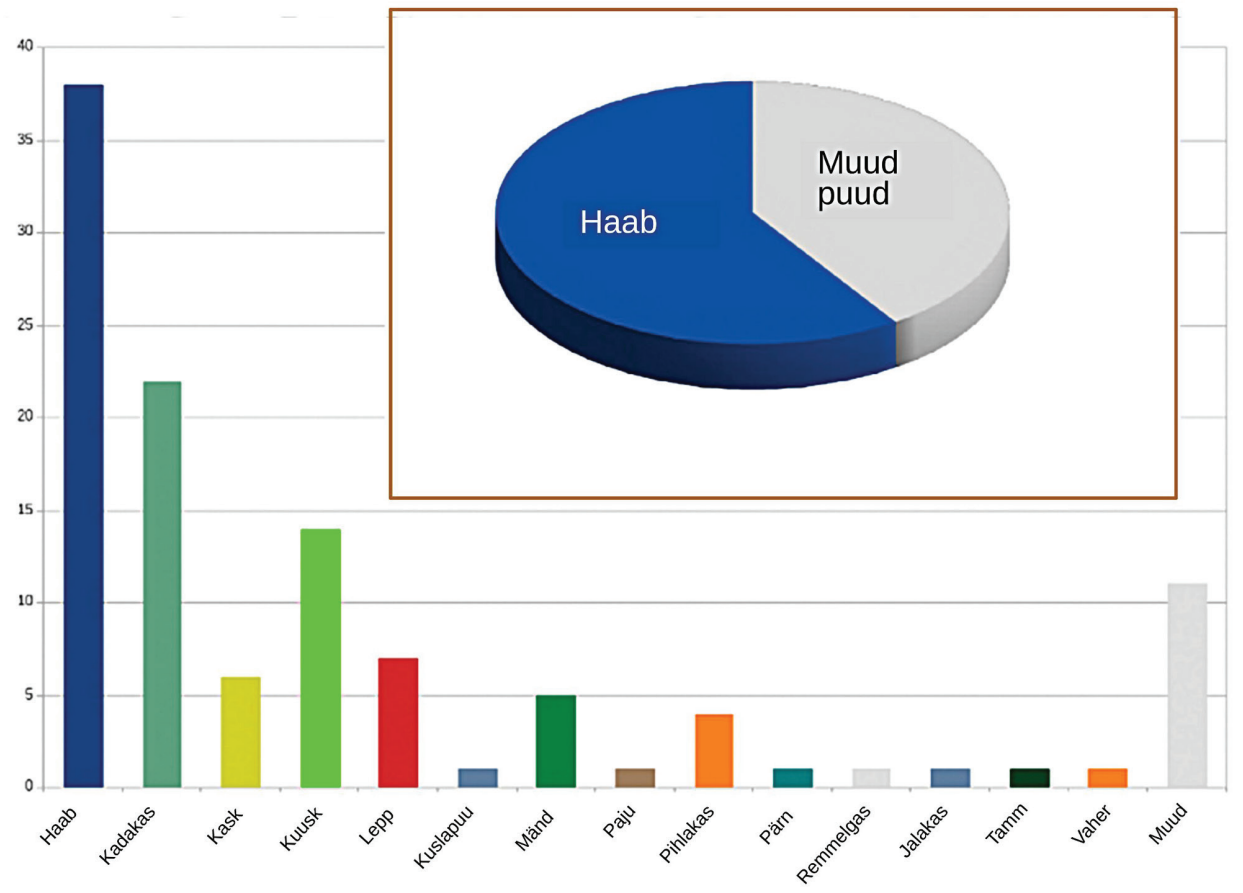

Joonis 3. Puuliikide jaotus Jeesusega seotud tekstides.

Mütoloogiliste olenditena esinevad Jeesus, Jeesus ja Maarja, Maarja, Juudas (tema poob ennast peamiselt haava otsa), Elias (ainult üks tekst), Kurat ehk Vanapagan ja Jumal ehk Vanaisa. Teatud mütoloogilise olendi motiive leidub ka naisel (põgeneb ega saa varju [haava lehed värisevad], teostab lageraiet [puud lõpetavad rääkimise]) ja veel mõnel puude omaduste kujunemisega seonduval tegelasel.

\section{Jeesusega seotud etioloogilised legendid}

Kuna antud tekstihulgas on Jeesus tähtsaim tegelane ja paljud puude omadused on suuresti temalt saadud, siis lähtume teemat arendades Jeesuse elu kronoloogiast. 


\section{*1 Austus(e puudumine)}

Haavalehed värisevad, sest

haavapuu ei näidanud üles aupaklikkust, kui Maarja koos Jeesusega metsas hulkus (üks tekst) - Maarja;

haavapuu ei kummardanud Jeesust ei metsas ega hiljem ristil (seitse teksti) - Jeesus;

haavapuu ei kummardanud Vanaisa (Jumalat), kui see metsas jalutas (kolm teksti) - Jumal.

\section{*2 Jeesuse piitsutamine. Paju}

Kuna Jeesust olevat pajuokstega piitsutatud, jääb paju väikeseks

Paju palus oma sugu maa pealt ära kaodata, et tema küllest on võetud vitsad, millega Jeesust pekseti, piits oli jäänd koju.

Siis oli üteld Jeesus: "Sina ehid ise ennast, laiendad, peotäis on sul seisupaika, kus sa seisad, ja sa ise ajad ennast laiali ja mingit tarbepuud sinust ei pea saama kui aga vitsa.” (ERA II 54, 221 (241) < TartuMaarja khk)

\section{*3 Jeesuse rist}

Jeesuse rist oli tehtud:

haavapuust (kümme teksti), sellepärast lehed värisevad; alumine risti puu oli tehtud haavast (üks); kadakast (viis teksti), üks põhjuseid miks kadakas väikeseks jäi; pihlakast (üks tekst - marjal on rist); pihlakast ja kadakast (üks tekst - marjal on rist, püstpuu vist pihlakas, põikpuu kadakas, selgesti ei tea); kuslapuu (üks tekst - sellepärast on korralikku kuslapuud raske leida); lepp (üks tekst - seetõttu on puit punane); kuusk (üks tekst - okste küljes rist); tundmatu (üks tekst, mingi haruline puu).

Mispärast on kadakas kängu jäänud. Kadakas oli vanasti niisama sirge puu kui teisedki puud. Kui Jeesus risti löödi, sis löödi ta kadakast tehtud ristipaku peale. Kui Jeesus ristipakku kandis, oli too väga raske, nii et Jeesus mitu korda ära nõrkes, siis vandus Jeesus puu ära, millest tema 
rist oli tehtud ja ütles: “Jäägu sa kiduraks ja kängu, et sust enam ühtegi riistapuud ei saa teha." Sellest saadik ongi kadakas nii kiduraks ja kängu jäänud. Enne taevasseminekut sai jälle Jeesus kadakaga kokku ja alustas ka kadaka juurest taevasse minekut. Ehkki ta kadaka puu juurest taevasse läks, ei andnud ta kadakale enam ta vana sirgust ja ilu tagasi, vaid jättis kadaka marjadele mälestuseks ristimärgi peale. (ERA II 150, 442/3 (67) < Räpina khk)

\section{*4 Jeesus kannab risti}

Haab ja kadakas (üks tekst - marjal on rist)

Kui Jeesus risti kandis ja väsinud oli, siis ta tahtis risti haavapuu najale panna, et ise puhkaks. Haav ei ole võtnud Jeesuse risti oma najale, siis Jeesus pannud risti kadaka najale ja kadakas oli risti lahkeste oma najale võtnud. Jeesus teinud siis kadaka otsa ristimärgi. Sestsaadik haavalehed värisevad. Kadakamarjadel on rist otsas ja kadakas on püha puu. Kui kadakas tules põleb, siis ta naerab rõõmsaste. Kui müristamise vihma ajal kadaka varju minnakse, siis võib julge olla, et välk pihta ei löö. (ERA II 129, 350/1 (16) < Rapla khk)

\section{*5 Jeesuse palve}

Jeesus palvetas enne ristilöömist haavapuu all, sellest haavalehed värisevad (üks tekst).

\section{*6 Jeesuse ristilöömine}

Ristilöömisel ei tunne haab kaasa (kaks teksti), Jeesus pani lehed värisema (vt näide punkti Haab alguses).

Haab nägi ristilöömist, kurbusest hakkasid lehed värisema (kaks teksti).

\section{*7 Jeesus läks taevasse}

Kadakalt (neli teksti, marjal on rist)

Kadakalt ja haavalt (neli teksti, marjal on rist, haab ei kandnud) 
Miks haavalehed värisevad ja miks kadakmarjal on rist otsas.

Jeesus tahtnud haava otsast taeva minna. Haab ütelnud, et tema ei kanna Jeesust ära.

Siis Jeesus läinud kadaka otsast taeva.

Sellest ajast haava lehed värisevad ja kadakmarjal on rist otsas. (ERA II 265, 259 (81) < Reigi khk)

\section{Jeesus ja Maarja}

Need tegelased esinevad peamiselt varju otsijatena, kas siis enda peitmiseks, või vihmavarjuks. Maarja neab varju mitte andvat haaba, et selle lehed väriseksid (kolm teksti), kuusk annab varju ja saab igihaljaks (neli teksti).

Haab ei austa Maarjat ja Jeesust, seepärast lehed värisevad (kaks teksti).

Marija Jesuse Ema läks, Jessu sülles, kuhugi, vihm hakkas sadama. Ta astus haava alla vihmavarju. Haab ütles, ära talla minu juuri, siis hakkasid tal lehed värisema.

Marija läks kuuse alla see oli rahulik andis neile vihmavarju, Marija soov oli, et ta ümber aasta haljas oleks. (KKI 42, $178<$ Iisaku khk)

\section{Maarja}

Maarja esineb üksinda nendes tekstides väga harva, peamiselt kohtab teda seoses hiiepuudega, ühes setu tekstis (E 25326 (b) < Oudova) ollakse lausa veendunud, et hiites palvetatigi neitsi Maarja nimel. Ortodokslikult Setumaalt pärinevad ka kaks teksti männi otsas kükitavast Maarjast, nt

Kirkut oli tahetud algul teise kohta teha (nn juudamaja Tuhkvitsa paremal kaldal Obinitsa küla kohal). Päeval tehti, öösel lammutati. Selline väike müür on veel näha. Siis tehti mändide juurde. Püha Maarja istus seal männis - see on jumalamänd. Selleks tehti sinna. (RKM II 44, 511 (1) < Setumaa, Obinitsa)

Mujal Eestis tuntakse nt Räpina lähedal Maarjamäge, mida on peetud pühaks paigaks ja rootsi sõdurite matmiskohaks, praeguseks on mägi teedeehituse liivana laiali kantud, samuti on Maarjaga seostatud nn hiiepuid. Tuntud on ka maarjakask, mille teket seletatakse: 
Kased mille oksad nõres alaspoole ripnevad, need olla Maarja kased. Jeesuse ema oli nende al üks kord Jeesus süles nutnud - ka kask kurvastanud. (H II 54, 115 (15) < Ambla khk)

\section{Eelias}

Prohvet Eelias esineb ainult ühes valikutekstis:

Kadakas olnud ennemuiste suur ja sirge puu, kandnud väga häid ja magusa maitsega söödavaid marju. Aga kui prohvet Eelias kadaka all maganud, tulnud temal söögiisu, pole aga kusagilt saada olnud. Katsunud kadakamarjadega isu kustutada, aga need olnud sel korral veel alles toored. Selle üle pahandanud ennast Eelias ja vandunud kadaka ära, ütelnud, et "sa mind pole jõudnud, ei saa enam ilmaski söödavaid marju kandma." Sest saadik jäänud kadakas marjade ja kasvu poolest kängu. (E 30557 (7) < Varssavi < Nõo khk)

\section{Juudas}

Juudas esineb Jeesuse äraandjana, kes poos ennast haavapuu otsa (kümme teksti). Lisaks on veel ühes tekstis haavapuu lehtede värisemise põhjuseks, et keegi poos end haavapuu otsa, teda on kasutatud poomiseks ja tal on inimestest kahju (üks tekst), tema all on tapetud (üks tekst).

Miks haavalehed värisevad. - Eesuse rist olnud selle puust tehtud. - Teised räägivad jälle, et Juudas oli sinna otsa ennast üles poonud. (ERA II 191, 431 (19) < Muhu khk)

\section{Vanaisa, jumal}

Haab ei ole jumalale tänulik (kaks teksti).

Kui Vanaisa oli metsa kasvama pannud, ühes kõik puud ja põõsad iluehtes õitsema, siis oli ta kord vaatama läinud, kas kõik nii alles-korras, nagu ta iluks istutanud, kaunistuseks kasvatanud. Kui Vanaisa metsa jõudnud, kumardanud kõik teised puud tervituseks tema ette maani, kuid 
haavapuu ei liigutanud end ja seisnud sirgelt omal kohal. See pahandanud Vanaisa, et haavapuu, tema anni eest tänulik ei mõistnud olla ja ütelnud: "Eluotsa, ööd kui päevad peavad sinu lehed nagu kahetsuseks järjest värisema, et sa nii mõistmata teiste seas oled olnud.” (ERA II 146, $89(57)<$ Saarde khk)

\section{Vanapagan, Kurat}

Ka vanapagan ei leia haava alt vihmavarju (üks tekst). Lisaks värisevad haavalehed sellepärast, et vanapagan olla haavale otsa jooksnud (üks tekst).

Kord olnud vanapaganal hirmus kiire, sest Kalevipoeg kihutanud teda taga. Vanapagan olnud nii hirmsa näoga ja väsinud, et ei näinud, kuhu jookseb, pand ikka otse edasi ja ikka edasi. Ta ei märganud, kui jõudis metsa äärde. Metsa ääres kasvas suur haab. Vanapagan jooksnud vastu puud. Sest ajast peale hakkas haab värisema, sest ta kardab veelgi, et vanapagan võib talle otsa joosta. (RKM II 468, 159 (9) < Simuna khk)

Oma kõhutuulega põhjustab kurat kuusehalgude tules praksumise (üks tekst) ja suitsu (üks tekst) tekke.

Sell päeval kui Jeesust risti löödi nutsivad kõik rahvas, kurat nägi seda, et Jesuse pärast rahvas nutsid. Läks ruttu metsa laskis sita haisu iga puu juure peale ja ütles: "Tema pärast nutate nüid, aga minu pärast nutate iga kord kui tuld teede." (H II 40, 1056 (3) < Tallinn)

\section{Naine}

Naine põhjustab haavalehtede värisemise, kuna mees jääb puuraiumisel puu alla (üks tekst), naise keel on haavalehest (üks tekst), haab ei anna naisele varju (neli teksti).

Haava lehed värisevad sellepärast, et naise keel on tehtud haava lehest ja naise keel ei seisa ka paigal. (ERA II 13, 477 (11) < Simuna khk)

Ka on naine põhjustanud puude rääkimise lõpetamise, tormates kirvega metsa lageraiet tegema, kui mees oli tühjalt tagasi tulnud. Tavaliselt oli puude rääkimise lõpetajaks Jeesus. 


\section{Vari}

Teine puude omaduste tekkimise seletamise oluline motiiv on vari. Vari on vana sõna ja seetõttu vägagi laia tähendusväljaga. Praegusel juhul on mütoloogilistel tegelastel, kes annavad puule mingi omaduse, tarvidus olla vihmavarjus, päikese- või palavusevarjus, tuulevarjus, tormivarjus, peidus. Mõnes tekstis on varju iseloom täpsemalt spetsifitseerimata. Lehtpuud tavaliselt keelduvad varjust, varju on andnud ainult lepp (üks tekst), pärn (üks tekst), vaher (üks tekst). Varju mitteandmine on üks sagedasemaid haavalehtede värisemise põhjuseid.

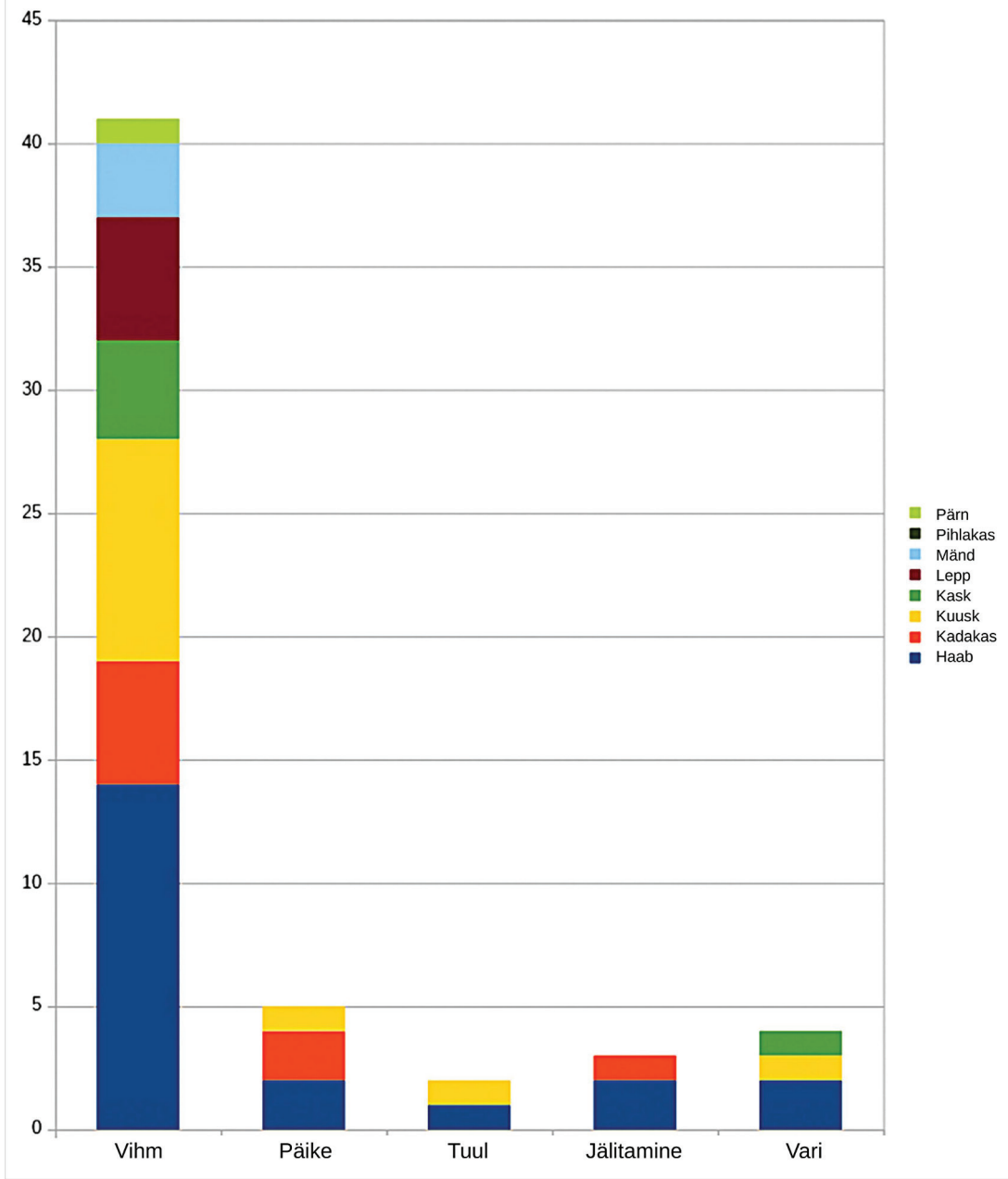

Joonis 4. Puuliikide ja antavate / mitteantavate varjude jaotus tekstides. 


\section{*1 Vihmavari}

Kõige rohkem on meie tegelased otsimas vihmavarju. See on siinse kliimaga täiesti tüüpiline, et näiteks vaene Jeesus, kes parajasti mööda metsa hulgub, jääb tiheda vihma kätte ja hakkab kiiresti varju otsima.

Ennemuiste olid kõik puud aasta läbi lehes. Kord aga kõndinud Jeesus mööda teed, korraga hakanud vihma sadama, Jeesus läinud esiteks ühe kase alla vihmavarju, kask aga lasi vihma sorinal läbi. Siis läinud lepa alla, aga ei paremat ühti, siis läind vana tugeva tamme alla, aga ka see ei hoidnud vihma kinni, ja lasi üsna meelega vee läbi joosta. Nüüd aga läind männi alla, sie hoidnud juba vihma kinni, nü̈̈d läind veel kuuse alla, see hoidnud vihma täiesti oma lehtede vahel kinni. Teised puud naersid omavahel mis nüüd nood võivad varjata, neil pole ju õigeid lehtigi, nagu nõelad, mis need ka vihma vastu peavad, kuusk ja mänd aga pü̈̈dsid osavasti vihma tibad kinni, ja hoidsid neid kõik oma nõela moodi lehtede küljes. Jeesus aga ütles: "Et te mänd ja kuusk mind vihma eest olete varjanud, siis peate ainult teie aasta läbi lehti kandma, teie teised uhked puud, kes te neid naersite, peate aga pool aastat häbiga oma lehtedest ilma olema. Ja pool aastat võite neid kanda." Nii on siis jäänudki, kuusel ja männil on oma lehed alati küljes, aga teised puud peavad pool aastat alasti olema, ja häbiga oma uhkust kahetsema. (H II 14, $224(18)<$ Ambla khk)

Vihmavarjuga seotud tekste:

a) haab ei anna varju (kolm teksti, varju otsivad Jeesus, kurat);

b) haab ei anna varju, kadakas annab (neli teksti, lehed värisevad, marjal on rist);

c) haab ei anna varju, kuusk annab (neli teksti, lehed värisevad, kuusk igihaljas, varju otsivad Jeesus, Jeesus ja Maarja);

d) kuusk annab, muud puud ei anna (kolm teksti, igihaljas, raagus);

e) kuusk annab, kask, haab, remmelgas, lepp ei anna (üks tekst, igihaljas, raagus);

f) kuusk annab, kask, mänd, lepp, pärn, saar ei anna (üks tekst, igihaljas, raagus);

g) kuusk annab, kask, mänd, lepp, tamm ei anna (igihaljas, raagus);

h) lepp annab, kask, haab ei anna (üks tekst, lepale pehmed lehed, varju otsivad Maarja ja Jeesus);

Kui sündis Jeesus (Isus), siis taheti teda ära tappa. Ta ema põgenes ja tahtis kuhugi varju minna. Tahtis minna kase varju. Vanasti puu kõneles. Kask aga ütles: "Ei saa võtta: mul on väiksed lehed." Läheb tema haaba 
manu. Haab kõneleb: "Ei saa võtta. Nüüd on vihm. Ei ole sind kuhugi panna." Jumalasünnitaja (Bogoroditsa) vastas haabale: "Noh, värise kogu oma eluiga! (Nu, trjasisja ves' svoi vek)." Vaat, haab värisebki, olgu kui või vaikne ilm.

Läks tema lapsega lepa manu. Lepp (ol'ka) andis varju. Jeesuse ema onnistas (blagoslovila) leppa, et sel oleksid suured pehmed lehed ja et keegi teda ei puutuks. (ERA II 61, 425/6 (3) < Lutsi, Ludza 1)

i) haab ei anna, pärn annab (üks tekst, pehme kohisev leht, puud räägivad).

\section{*2 Päikesevari}

Meie kliimas tundub uskumatuna, et keegi vajaks päikesevarju, aga nii siiski on:

a) haab jälle ei anna varju (kaks teksti, varju otsib Jeesus)

b) kadakas annab varju (kaks teksti, varju otsib Jeesus, marjal on tänuks rist)

Olnud väga palav päev. Jeesus kõndnud pikka teed, ta olnud väga väsinud ja vajanud puhkust ja varju põletava päikese eest. Seal leidnud ta ühe paksu kadaka põõsa, istunud selle varju ja kadakas andnud hääd puhkust. Kui Jeesus minema hakanud, siis puudutanud kadaka marju ja ütelnud: "Sinu marjadel peavad selle täheks marja otstes olema rist." Sellepärast võivat ka äikese ajal ainult kadaka varju minna vihma eest, sest kadaka külge pikne ei löövat. (ERA II 202, 307 (28) < Pilistvere khk)

\section{*3 Vari, peidus}

a) Vaher peidab Jeesust oma laiade lehtede vahele (üks tekst).

b) Kuusk varjab Jeesust ja Maarjat, Maarja muudab ta igihaljaks (üks tekst).

c) Kadakas peidab naist mehe eest, kes tahab teda tappa, kadakas jääbki edaspidi madalaks, et varju anda (üks tekst).

d) Haab ei anna pageja Maile varju vanapagana eest, püha tamm peidab ta paksude lehtede vahele (üks tekst).

\section{*4 Varju alla ei saa}

a) Haab ei anna Jeesusele varju ja saab värisevad lehed (kolm teksti).

b) Haab ei anna mehetapjale naisele varju ja saab värisevad lehed (üks tekst). Sama motiiv on tuntud ka lüroeepilistes laulus "Mehetapja", kus 
mehetapjast naine põgeneb ja palub varju jälitajate eest. Kui haab keeldub, siis neab põgeneja haavalehed värisema nagu väriseb tema hirmunud süda rinnus, nt H II 54, 458/464 (158) < Ridala khk (1896).

c) Haab ei anna varju piinajate eest põgenevale naisele ja saab värisevad lehed (üks tekst).

d) Haab ei anna varju sõja eest põgenevale naisele ja saab värisevad lehed (üks tekst).

e) Haab ei anna varju tapja mehe eest põgenevale naisele ja saab värisevad lehed (üks tekst).

f) Haab ei anna varju ühele (määratlemata keegi) ja saab värisevad lehed (üks tekst).

g) Kadakas ei anna varju Jeesusele (üks tekst):

Kadakas ei tahtnud Jeesust enda alla varju võtta, tahtis endale okaste asemele lehti.

Jeesus küsis: "Kas sa võtad mind enda varju alla puhkama?"

Kadakas ütles: "Ei võta. Mulle tuleb siia üks mees, kes annab mulle uued läikivad lehed ja nõelad puistab maha."

Jeesus küsis: "Kes too mees sul on, kust suguharust?"

Kadakas ütles: "Heebrea suguharust."

Jeesus küsis: "Kas sa ei võta mind enda varju puhkama?"

- "Ei võta."

Siis Jeesus läks ja ütles: "Jäägu sinule kõik sinu nõelad sind torkima ja mitte ühtegi lehte sa ei saa. Mina oleks sulle küll lehed andnud, aga Heebrea mehel ei ole seda väge."

Ja ongi kadakal okkad.

(ERA II 63, 127/8 (339) < Põlva khk)

\section{Paralleele käsitletud etioloogilistele legendidele}

Legende haavalehtede värisemisest tuntakse kogu Euroopas, kuid nagu alati, on neid süstemaatilisemalt käsitlenud slaavikeelsed uurijad, seetõttu refereerin lähemalt vene (Tatjana Agapkina) ja valgevene (Jelena Boganeva = Alena Bohaneva) käsitlusi. Kuna etioloogilised tekstid on 'rahvausu' komponent, tuleb eelnevalt defineerida keskkond, kus nad levisid. Eesti valdavalt protestantlikku luteri kirikut võib lugeda üsna vabameelseks, seevastu ortodoksne ühiskond on kanoonilisem ka rahvausus. Seega kui meie etioloogilistes legendides on tegelased varieeruvamad ja lausa seinast seina, alates Jeesusest ja lõpetades perenaisega, siis slaavi rahvastel on kinnipidamine apokrüüfilistest motiividest jäigem ja ka tegelaste arv piiratum. 


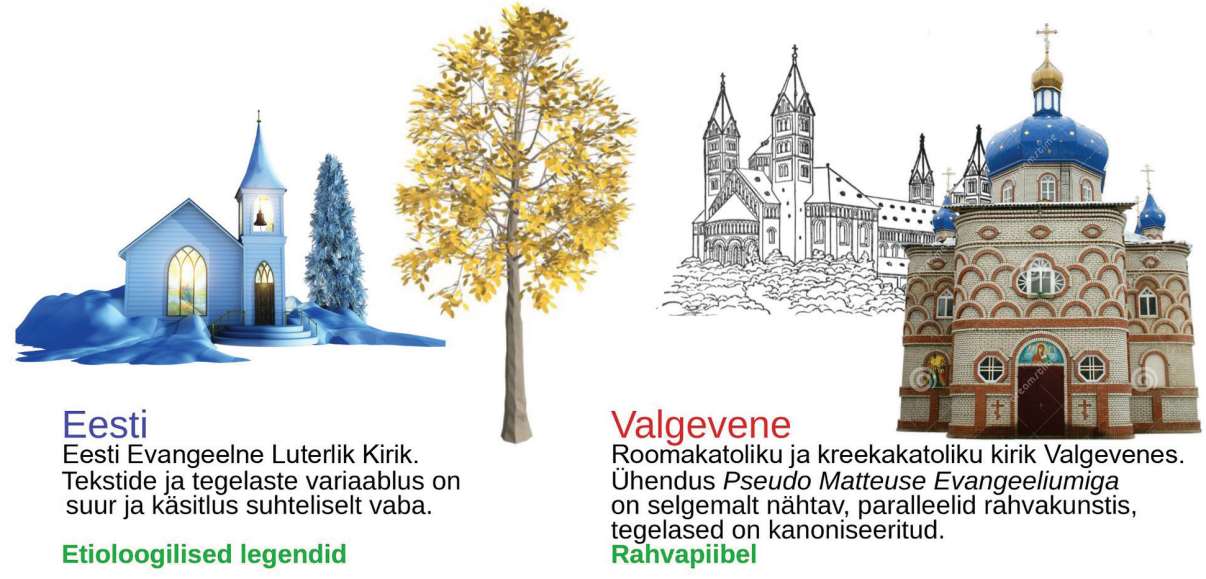

Joonis 5. Eesti ja Valgevene religioosse tausta piltlik võrdlus.

Seetõttu käsitlevad slaavi uurijad etioloogilisi legende nn rahvapiibli komponendina. Suhtumine haaba on slaavlastel rangem kui meie lugudes. Haab on naissoost, needuse tõttu viljadest ilma jäetud puu, mida ei istutata elamute lähedale, mustades loitsudes võib ta esineda ilmapuuna, ka teispoolsuse puuna ning osaleda isegi deemonite inkarnatsioonis (Agapkina 2019: 228-273). Idaja osaliselt ka lääneslaavlased loevad haaba mittepuhtaks ja neetud puuks, lõunaslaavlased on oma hinnangutes neutraalsemad. Meie etioloogilistes legendides selliseid otseseid hinnanguid ei ole antud.

Valgevenes hoitakse legendide põhimassiivi andmebaasis "Valgevene etnolingvistiline atlas" (Белорусски этнолингвистически атлас БФЭЛА etnolingvistika ja folkloorisektori hallatav) ja Teaduste Akadeemia Valgevene kultuuri, keele ja kirjandusuuringute keskuse folkloristika ja slaavi rahvaste kultuuriuuringute osakonna folkloorikogus. Tekstide arv, mis käsitlevad puude omaduste kujunemist mütoloogiliste/piiblitegelaste tegevuse tagajärjel, on samas suurusjärgus - 106 teksti. Seos pseudo-Matteuse evangeeliumiga (Сказание о бегстве Пречистье Девь Богородиць с Боголла-дениел в Ezunem) on konkreetsem ja selgemalt märgatav, kuid apokrüüfilistes tekstides ei ole puud personifitseeritud (Boganeva 2019). Erinevalt meie puudest Valgevene puud ei räägi. Rääkivate puude motiivi levik algab kusagil Lätis.

Lisatud kaart on sünteesitud Jelena Boganeva artiklis avaldatud Valgevene rahvapiibli siinkäsitletud motiivide kaartidest - kaart $\mathrm{nr} 7$, Haab kui neetud/ patune puu ja kaart nr 9, Lahked, onnistatud puud. Kaardi tingmärgid ülevalt 


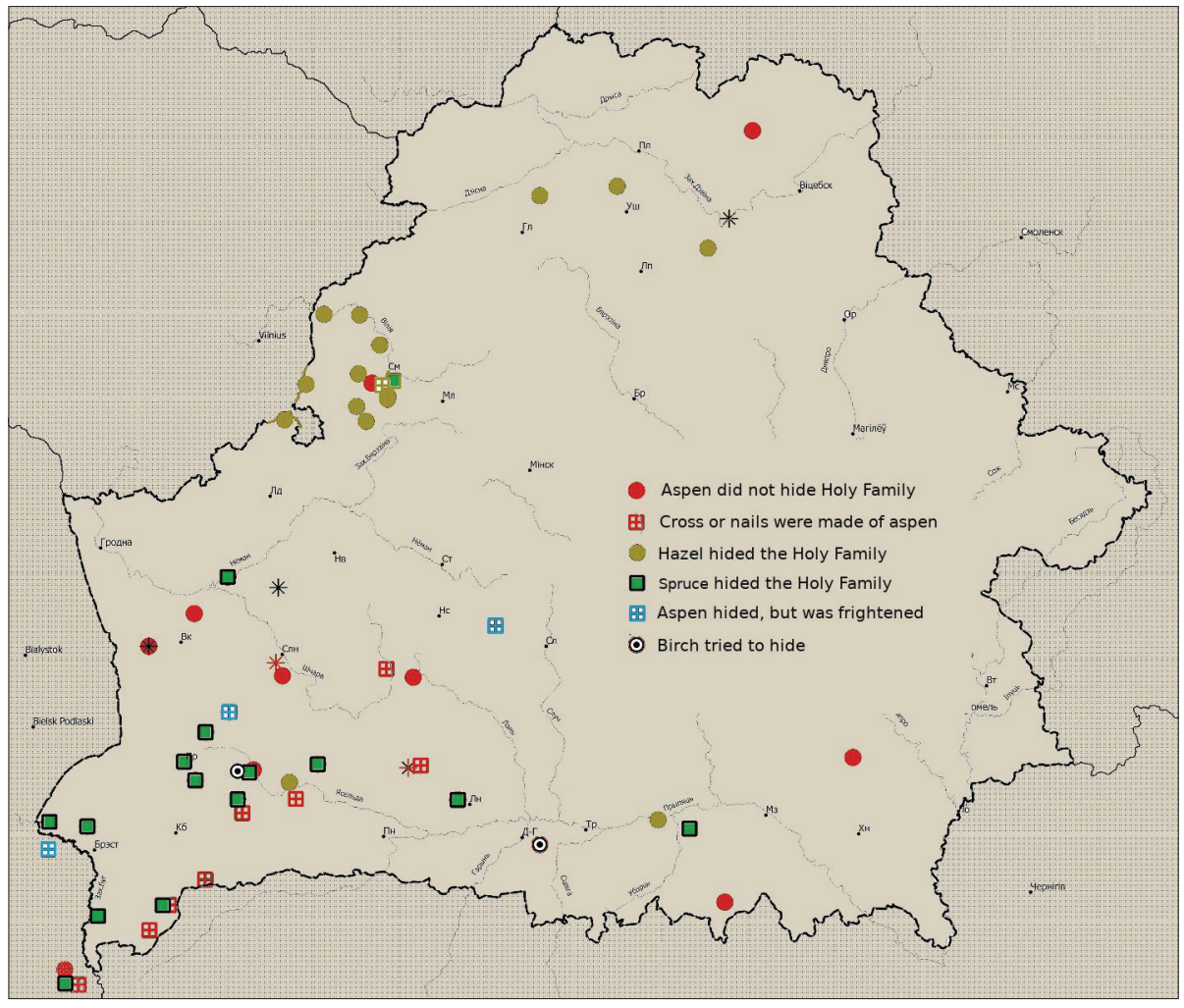

Joonis 6. Valgevene levinumate puudega seotud rahvapiibli motiivide levikukaart.

alla: 1. haab ei anna varju; 2. Jeesuse rist või naelad on tehtud haavapuust; 3. haab ei varja, kuid pähklipuu peidab püha perekonna; 4 . kuusk varjab püha perekonda; 5 . haab varjab, kuid on hirmunud; 6 . kask üritab varjata. Nagu eelnevalt märgitud, on neis tekstides toimuvad tegevused ja tegelased kanoonilisemad ning vähem varieeruvad võrreldes Eestis kogutuga, kuid ka meil on nähtav tihedama võraga puudele omistatav positiivne varjund.

\section{Teisi puude omadusi}

Mõned usundilised tekstid puudest ei mahtunud hästi artikli põhiosa kontseptsiooni, seetõttu avaldan huvitavamad siinkohal lisana. 


\section{*1 Miks haavapuu koor on mõru}

Haavapuu lasknud vaiksel õhtul nutusahinat, tuult ei olnud, kõik teised puud vaikisid. Jumal küsis haavapuult miks sa nutad, haavapuu vastas: "Selle pärast et mu koor on nii maitsev, ma tahaks et mu koor oleks viha kui sapp." Jumal andnud haava koorele viha maitse, aga jänesed ütlesid, et se viha maitse ei tee midagi, ja söövad edasi. (RKM II 309, 461 (843) $<$ Rakvere khk)

\section{*2 Miks kask on valge}

Kord vanal ajal, mil vanapagan alles poisikene oli, kutsus vanajumal kõik puud oma juurde peole. Kui kõik teised puud peale kase olid vanajumala juures, saatis ta käskjala kase järele. Varsti tuli käskjalg tagasi ja teatas, et kask alles kammib juukseid ja on särgiväel. Vanajumal ootas vähe aega ja kui kask ikka veel ei ilmunud, saatis ta uuesti käskjala järele. Käskjalg tuli teist korda tagasi ja teatas, et kask ikkagi alles särgiväel, ta ei saavat oma juukseid nii ilusasti kammida kui tahtvat. Nü̈̈d vihastus vanajumal, kuid lootis siiski kase tulekut. Et ootamine pikale jäi, saatis vanajumal käskjala kolmandat korda kase järele. Kaselt tuli sama vastus. Vanajumal sai päris vihaseks ja ütles: “Jäägu siis kask eluks ajaks oma kammitud juustega ja särgiväele, kuna kõik teised puud peavad peoülikonda kandma!”

Seepärast on kask valge ja teised puud tumeda koorega. Kase kammitud juuksed või oksad on ka tõesti ilusad... (ERA II 224, 73/4 (1) $<$ Tallinna l)

\section{*3 Miks lepp on punane}

Vanasti olnud nii naistel kui ka meestel kuuriided. Üks mees ehitanud maja ning raiudes leppa istunud kaksiti palgi (st lepapalgi) peal, ning teinud selle punaseks. Vanajumal küsima: "Miks sa ei korja ennast?" Mees vastu: "Naistel on laiad riided, meestel aga kitsad, ei saa korjata." Vanajumal pannud siis sellest ajast lepa külge puna, jättes mehed vabaks. (ERA II 131, 654 (7) < Ambla khk)

Teine variant oli eelnevalt juba mainitud: Jeesuse rist oli lepapuust. 


\section{*4 Pihlakas, karjaõnn}

Kevadel loomi välja ajades esimest korda, tahtis Kaigotsi mees loomi läbi pihlapuu ajada, et loomad oleksid huntide ja kõige paha eest kaitstud. Ka Jeesus olevat pihlapuu läbi ajanud. Aga kust võtta nii suur pihlapuu. Tulnud siis mõttele, et ega pole teada, mis pidi läbi pihlapuu peab ajama, kas pikuti või põigiti. Läks siis ja tõi metsast pihla vembla, sidus otsad kritsiga kinni, et lõhki ei läheks ja ajas siis vembla keskelt lõhki. Nüüd läks peremees ühe värava posti juure, perenaine teise juure ja tõmbasid lõhkise vembla harud laiali. Sulane läks lauta ja hakkas loomi vitsaga ükshaaval läbi pihla ajama. Kui loom oli parajasti pihla sees on, pidi sulane loomale kaks kõpsu vitsaga pihta lööma ja ise ütlema: „Piima ja võid." Nõnda ajati kõik loomad läbi pihlapuu... (ERA II 9, 82/3 (1) $<$ Emmaste khk).

\section{*5 Kadakamari oli Jeesuse toit}

Minu tädi oli kirikuskäija, oli maru-usklik. Tema rääkis:

Kadakas olnud. Jeesusel olla nii nälg olnud, kuskilt ei ole midagi suhu pista saand. No siis läind kadaka juurde ja kadaka marju söönd. Siis oli väike lauluke ka selle kohta paari-kolme-realine:

Oh kadakas, sa kaunis puu, sa Jessu esi-einespuu.

Su külles kena marjake ja marja otsas ristike.

(RKM II 251, 648/9 (82) < Kadrina khk)

Sarnase sisuga on veel Vilbaste, TN 10, 248/9 (1.5) < Rakvere khk.

Prohvet Eelija meelest olid marjad toored ja ta needis kadaka väikeseks.

\section{Kokkuvõte}

19. sajandi lõpukümnenditel ja 20. sajandi esimeses pooles kirja pandud etioloogilised lood ei ole seni leidnud Eestis põhjalikku käsitlemist. Kahjuks hakati neid lugusid koguma suhteliselt hilja ja nende interpreteerimine viibis huvitavamate uurimisülesannete tõttu. Takistuseks võis olla ka asjaolu, et näiteks puudega seotud jutud on lähedalt seotud kristlike legendide, apokrüüfiliste käsikirjadega ja muude kristlike rahvapäraste seletuslugudega. Lood levisid sajandeid kui rahvakristluse ja kristliku kirjasõna sümbioos ning jäid 
selle tõttu 20. sajandi rahvaluuleteaduses äärealadele. Just selle pärimusliigi juures on olulisel kohal interkultuurilised ja transkultuurilised protsessid ja vastastikused mõjutused.

Materjali hulgas torkab silma haavaga seotud pärimuse prevaleerimine kõikides jutumotiivides ja tegevustes, aga ka seaduspärasus, et tegemist on lugudega, mille juures domineerib üks motiiv, samas kui ülejäänutest on vähe üleskirjutusi või on need ainukordsed.

\section{Tänuavaldused}

Artiklit on toetanud Eesti Teadus- ja Haridusministeerium (IUT 22-5) ja EU regionaalarengu fond Eesti-uuringute Tippkeskuse (CEES - TK 145) vahendusel. Artikkel on osa müüdilise pärimuse analüüsidest. Artikli tehnoloogiliseks aluseks on aastaid arendatud sisestustekstide parandus- ja analüüsikeskkond Skriptoorium.

\section{Allikad}

Kasutatud on Eesti Kirjandusmuuseumi folkloristika osakonna poolt digiteeritud tekste järgmistest käsikirjalistest kogudest:

H - Jakob Hurda rahvaluulekogu, 1860-1906

E - Matthias Johann Eiseni rahvaluulekogu, 1880-1934

ERA - Eesti Rahvaluule Arhiivi rahvaluulekogu, 1927-1944

KKI - Keele ja Kirjanduse Instituudi murdekogu

RKM - Eesti TA Fr. R. Kreutzwaldi nimelise (Riikliku) Kirjandusmuuseumi (nüüd Eesti Kirjandusmuuseumi) rahvaluule osakonna rahvaluulekogu, 1945-1996

Vilbaste - Gustav Vilbaste rahvaluulekogu, 1907-1966

\section{Kirjandus}

Aa US = Aarne, Antti 1918. Estnische Märchen- und Sagenvarianten. Verzeichnis der zu den Hurt'schen Handschriftsammlungen gehörenden Aufzeichnungen. Folklore Fellows' communications 25. Hamina: Suomalainen Tiedeakatemia.

Agapkina, Tatjana 2019. Derev'ia v slavianskoi narodnoi traditsii: Ocherki. Moskva: Indrik. 
Boganeva, Jelena 2019. Sviatye i greshnye derev'ia v belorusskoi narodnoi Biblii: istochniki, arealy, paralleli. Sbornik materialov IV Vserossiiskogo kongressa fol'kloristov. Moskva.

Mälk, Vaina \& Sarv, Ingrid \& Viidalepp, Richard 1967. Eesti muinasjutud. Tallinn: Eesti Raamat.

PM - Pseudo-Matteuse Evangeelium = The Gospel of Pseudo-Matthew. From: AnteNicene Fathers Vol 81886 ed Alexander Roberts, Sir James Donaldson, Arthur Cleveland Coxe - 1886. The Gnostic Society Library. Christian Apocrypha and Early Christian Literature (http://www.gnosis.org/library/psudomat.htm - 20. november 2019).

Tuczay, Christa Agnes 2017. German. The Bible in Folklore Worldwide. Ziolkowski, Eric (toim). Volume I. A Handbook of Biblical Reception in Jewish, European Christian, and Islamic Folklores. Berlin \& Boston: de Gruyter, lk 133-156.

\title{
Summary
}

\section{Why do aspen leaves tremble? Main features of tree- related aetiological texts}

\author{
Andres Kuperjanov \\ Researcher, Department of Folkloristics \\ Estonian Literary Museum, Estonia \\ cps@folklore.ee
}

Keywords: aetiological legends, aspen, berry with a cross, folk bible, Jesus, trees, text corpus, trembling leaves

The aim of this article is to provide an overview of tree-related aetiological legends, the main motifs of these tales, and the characters occurring in them on the basis of digitised materials. The article presents motifs related to the most popular characters in the tales, followed by the frequent motifs and sub-motifs by different species of trees. Since Estonian materials are relatively difficult to acquire and have not been translated into other languages, this article tries to introduce as many sample texts as possible. Where possible, story types have been pointed out by making use of Antti Aarne's catalogue (1918) and the academic fairy tale anthology compiled by Vaina Mälk, Ingrid Sarv, and Richard Viidalepp (1967).

There are over 21,000 texts in the material digitised by the Department of Folkloristics of the Estonian Literary Museum, which are directly related to trees, and in addition to this, trees have been mentioned in other texts in nearly 400 different aspects. The most important of these are predominantly concerned with folk medicine, calendar traditions, folk astronomy, harvest predictions (predicting cattle growth and crops) and day-to-day household use. Many narratives about hidden treasures are also related to trees. Tree aetiologies (more than 100 texts) represent a specific group that shares common features with other types of lore and the Christian tradition, but these common occurrences also need to be specified. 
Unfortunately, these stories were collected relatively late, in the last decades of the 19th century, and the interpretation of these stories was delayed due to other research projects that were deemed more interesting. The fact that tree-related stories, for example, are closely connected with Christian legends, apocryphal manuscripts, and other explanatory Christian folk stories, may have also been a hindering factor. For centuries, aetiological legends spread as vernacular Christianity, serving as an interesting symbiosis of Christian scripture and verbal lore, and for this reason these texts remained on the fringe of 20th-century folklore studies. It is this type of lore that centres around intercultural and transcultural processes and interaction.

The predominance of aspen-related lore in all story motifs (trembling leaves) and activities stands out in the material. Aetiological legends follow a pattern whereby there is one dominating motif in these legends and very few or single records of other motifs. The most prominent character is Jesus, but Mary, Judas, Elijah, the Devil or Old Heathen, and God or Grandfather are also mentioned.

Andres Kuperjanov (filosoofiamagister) on Eesti Kirjandusmuuseumi folkloristika osakonna teadur, Eesti-uuringute Tippkeskuse liige. Tema huvikeskmes on olnud eesti rahvausund ja etnoastronoomia. Ta on avaldanud monograafia "Eesti taevas", artikleid rituaalsest aastast, etnokosmoloogiast ja etioloogiast. Praegu on ta keskendunud usundilistele juttudele, puudega seotud pärimusele ja etnoastronoomiale.

Andres Kuperjanov (MA in philosophy) is Research Fellow at the Department of Folkloristics at the Estonian Literary Museum, Estonia, and member of the Centre of Excellence in Estonian Studies. His research topics include Estonian folk religion and ethnoastronomy. His publications include a monograph Eesti taevas (Estonian Sky, in Estonian), chapters and articles on the ritual year, ethnocosmology, and aetiology. His current research focuses on belief narratives, tree lore, and ethnoastronomy.

cps@folklore.ee 